\title{
Sustainability of Vegetable Farming Self-Help Groups in Himachal Pradesh
}

\author{
Surinder Singh ${ }^{1 *}$ and B.S. Hansra ${ }^{2}$ \\ ${ }^{1}$ School of Agriculture, Indira Gandhi National Open University, New Delhi, India \\ ${ }^{2}$ Amity International University, Noida, Uttar Pradesh, India
}

*Corresponding author: singhsurin@yahoo.com (ORCID ID: 0000-0002-7451-3437)

Received: 23-03-2021

Revised: 25-05-2021

Accepted: 03-06-2021

\begin{abstract}
Farming families in states like Himachal Pradesh face enormous hardship in sustaining livelihood from fragmented small and marginal landholdings. Vegetable farming-based self-help groups have emerged as a significant transformation tool for the rural economy in hills. Now it is possible to address farm problems in a group rather than struggling for individual farms. Vegetable farming-based self-help groups have paved a new path in rural economic development. Self-help group is a small economic venture at the village level. It can be defined as sustainable if it can work for its basic goal of development by meeting out all day to day expenditures without any external aid while creating profit, social upliftment of members and without deterioration to the environment that ultimately brings prosperity in a rural area. Knowing the sustainability of self-help groups helps in planning and executing rural development policies. Various researchers developed various tools to assess the sustainability of self-help groups but these tools do not fit well for all geographical areas with diverse rural communities. Present study was conducted in Himachal Pradesh to assess the sustainability of vegetable farming-based self-help groups. The study reveals that women farmers constitute a major portion of SHG framework, the average size of SHG in Himachal Pradesh was 14, and the majority of the groups had bank linkages. The majority of self-help group members were contributing above ₹ 100 per/month and generally held group meetings once a month. 80.00 percent of the -help groups were found with above 90 percent attendance in monthly meeting and family problem was a major reason for non-repayment of loan. Self help group capabilities need to be strengthened by more training, village-specific training content, and better financial management for planning group corpus. As a policy intervention, self-help groups require more training on maintaining records and financial management, which can enhance the scope for cross crosslearning between self-help groups where SHGs could learn from the experience of better-performing one.
\end{abstract}

\section{HIGHLIGHTS}

( Self-help group is a small economic venture at the village level, and it can be defined as sustainable if it can work for the economic and social upliftment of its members while maintaining rural ecological system without any external aid.

0 Vegetable farming self-help groups has proved to be the sturdiest tool and a powerful conduit for empowering rural poor and help them to move from subsistence to sustainability.

(0 A study on the sustainability of self-help groups is very much required to ascertain the future viability of self-help groups.

( To be sustainable a self-help group must be financially as well as organizationally stable.

Keywords: Self-Help Group, Vegetable farming, Economic sustainability, Organizational sustainability, Himachal Pradesh

How to cite this article: Singh, S. and Hansra, B.S. (2021). Sustainability of Vegetable Farming Self-Help Groups in Himachal Pradesh. Int. J. Soc. Sci., 10(02): 153-161.

Source of Support: None; Conflict of Interest: None 
Himachal Pradesh is a small hilly state where small and marginal land holding is pre-dominant characteristics of agriculture. Most of the farming families in the state try to secure livelihoods from these fragmented landholdings, which are unpalatable to cope up with the inherited constraints of traditional agriculture. Poverty and unemployment are major problems faced by the rural community (Singh and Hansra, 2017). Collective efforts in the form of self-help groups (SHG) have projected a new horizon of possibilities over traditional individual farming. The self help group has proved to be the sturdiest tool and a powerful conduit for empowering rural poor and help them to move from subsistence to sustainability. Vegetable farming self-help groups help to minimize vegetable production constraints (Singh and Hansra, 2021) but still very less information is available on the sustainability of self help groups. Self-help group is a small economic venture at the village level, and it can be defined as sustainable if it can work for its basic goal of development by meeting out all day to day expenditures without any external aid while creating profit, social upliftment of members and without deterioration to the environment which ultimately bring prosperity in a rural area. Vegetable farming has paved a new path of economic development in a hilly state like Himachal Pradesh. Now farmers can harvest more monetary value per unit of land (Singh and Hansra, 2018). It has also been observed that the income of SHG members was increased substantially after joining SHG. Economic activities through vegetable farming self help group significantly supplement incomes of small and marginal landholder farmers. An increase in income had helped to reduce the levels of poverty to a great extent in several families (Kumar, 2018), and the age of self-help group is an important determinant of SHG sustainability as old self-help group members were better empowered when compared to new self-help groups in socio, economic and political dimensions (Harika et al. 2020). Government of Himachal Pradesh has also recognized SHG approach as an important economic driver in rural areas and has planned to achieve goal of setting twenty thousand more SHG with ₹ 1.75 crore bank credits by 2022 under sustainable development goals (GoHP, 2021). The importance of SHG as rural economy driver can also be recognized by government efforts to constitute more SHGs. Under NRLM, 4666 and 3384 SHGs were constituted from 2019-20 and 2020-21, respectively (GoHP, 2021). Government efforts towards the formation of more and more self-help groups are fruitful only if these SHGs are economically and organizationally sustainable. Group sustainability has a wider concern among donor agencies, practitioners, policymakers and academicians to achieve persistent benefit from self-help groups in financial intermediation (Das and Guha, 2019). Despite considerable achievements, the sustainability of self-help groups has been suspect because several essential services required by self-help groups are provided free or at subsidized cost by organizations that have developed these groups (Nair. 2005). However, measurement of sustainability is widely recognized as immensely difficult problem, as conventional monitoring and evaluation method, mostly using economic analysis, are considered insufficient to detect or quantify sustainability (Brown et al. 1987; Carpenter, 1993; Chopra, 1998).

Various researchers have developed many tools and scales to assess the sustainability of self-help groups. However, no tool fits well to all regions and geographical locations with diverse rural community structures. Mahajan (1998) identified four dimensions for the sustainability of microfinance programs in India: sustainability of demand, financial sustainability, organizational sustainability, and sustainability of the microfinance institutions. The sustainability of SHGs was also measured through the following assessment indicators: frequency and attendance of meetings, the volume of saving, rotation of own saving, development of financial skill, and quality of leadership (Tankha, 2002). The sustainability of SHGs was well established in terms of the increased value of assets and savings rate, better access to institutional loans, higher rate of repayment of loans, elimination of informal sources, and impressive social empowerment (Puhazhendi \& Badatya, 2002). Sen and Sircar (2006) conducted a study on SHGs in West Bengal, keeping in view the regularity of meetings, participation of members, group management, regularity of savings, loan disbursement, loan recovery, accounts and records, links with Panchyat Raj Institutions, livelihood 
engagement and social action as the indicators of quality assessment of SHG. Christen and Ivatury (2007) pointed that the sustainability of SHGs is associated with two factors: (a) whether adequate support services were provided to the SHGs and (b) whether the total costs of providing support services were paid from the operating income of SHGs. Ahlin and Jiang (2008) identified 'saver graduation' and 'tendency towards membership expansion' as key to making microfinance programmes sustainable in India. Kumari and Malathi (2009) emphasized that the sustainability of SHGs depends on several factors: improper maintenance of bookkeeping, restrictive government procedure, lack of training, low returns, and pressure on repayment of bank loans, inadequate loans and lack of cooperation among members. Feroze and Chauhan (2010) evaluated the performance of SHGs based on savings performance, loaning performance, repayment performance, and income and employment generation activity. The method of multistage Principal Component Analysis (PCA) is used to construct indices for each of the four performance indicators. Das (2012) assessed self help groups based on organizational constituent, savings \& credit, micro-enterprise development, network \& linkages, empowerment \& influence, and financial management aspects. It was observed that better time management and commitment to regular meetings contribute to groups' sustainability (Ramakrishna et al. 2013). To measure the performance of SHGs, Das and Bhowal (2014) selected seven broad indicators such as group constitution, organizational discipline, organizational systems, financial management and performance, external linkages, activities undertaken by group/members, and self-reliance. Financial indicators, SHG-bank linkages, social justice, social upliftment, internal cohesion, self-development of SHGs, gender equality, and social mobility were eight dimensions identified to develop cumulative scale, including 34 indicators by Devaki et al. (2015). Yadav et al. (2016) operationalized the performance of self-help group as a degree to which a group member had performed at their level in terms of capacity building, economic activity, communicability, andself-monitoring. The study of APMAS (2017) pointed that building strong social capital, particularly the SHG book writers is instrumental for the effective functioning and longterm sustainability of the SHGs. Singh (2017) suggested that for balanced development and proper utilization of SHG strength; they need good rating and categorization based on their capacity and skill. The sustainability of SHGs depends on the five principles or called panch sutra, which includes regular meetings, regular accounts, regular repayments, and adherence to terms and conditions (Kumar, 2017). Bhanot and Bapat (2019) reported that equitable access to credit, group savings, growth in savings, and loan utilization in income generation activities, members depositing a savings contribution or loan installment on each other's behalf, and distance from the bank are contributing factors for the sustainability of self-help groups. Das and Guha (2019) examined the status of group sustainability with the help of the multidimensional sustainability index of SHGs (MDSI ${ }^{\mathrm{SHG}}$ ) by combining organizational, managerial, and financial indicators of self-help groups. Knowing the capacity and skill of any SHG is possible only by studying its basic profile and sustainability aspects for which the present study was planned. It is argued that the financial and institutional sustainability of SHGs depends upon the quality and quantity of financial services that the groups provide to its members, how best the group mobilize savings from members, loans from banks and other credit agencies, and build group corpus for lending to their members (APMAS, 2017). In the hilly state like Himachal Pradesh, very little research work is done on the sustainability of SHGs; thus the present study was planned with the following objectives:-

1. To study the profile of vegetable farming self-help groups in Himachal Pradesh.

2. To study economic and organizational behavior of vegetable farming-based SHG.

2. To suggest possible measures for strengthening the sustainability of self-help groups.

\section{MATERIALS AND METHODS}

The present study was conducted in Himachal Pradesh. The state is having three administrative divisions (Kangra, Mandi, and Shimla), and all were included in the study to cover each geographical area of the state. 
Two districts were selected randomly from each division, and five vegetable growing self-help groups promoted by government institutes like DRDA under SGSY, NGO/ Bank, Agriculture department were selected randomly. Thus a total of 30 Self-Help Groups were included in the study. From each randomly selected -help group, one office-bearer of the group, either president/secretary/ treasurer, was interviewed to collect data on a pre-tested questionnaire. Variable for economic and organizational sustainability were selected as per NCAER (2008).

\section{RESULTS AND DISCUSSION}

\section{(I) Profile of Vegetable Farming Based Self-help Groups}

Before in-depth analysis of self-help group sustainability, it is essential to know the profile of the groups as it reveals the basic information about the groups. It also indicates whether the groups follow guidelines laid down by the promoter agencies and financial institutions. Eight parameters such as the age of the group, size, gender, social category, economic status of the group, promoter, number of years bank linkage, and training programs attended were studied and tabulated in table 1.

Age of Self-help Group: The age of self help group means the number of years from the formation of self-help group. Age of SHG helps to strengthen its organization and economic behavior as with an increase in age, a sustainable group tends to develop a good corpus and mutual understanding among members. The age-wise distribution of SHGs is depicted in Table 1. The maximum and minimum ages of SHGs were 12 and 3. The average age of the groups was 6.1 years. The majority of the groups (18) were above the age of 5 years, 12 were in the range of 3 to 5 years. The average age of 6.1 years indicates that vegetable farming-based -help group formation has gained major momentum in the state only after 2010 .

Size of group: The average size of the self-help groups was observed to be 14 members. It was observed that the majority of the group's (50 percent) size was 1315 (Table 1). It is seen that the number of the group members ranged from 10-20. This range was well within the norms of SHGs
Gender and social category: It is evident from the data presented in Tables $1 \& 2$ that 26 groups (86.67 percent) were female and 4 groups (13.33 percent) were male groups. The majority of the female groups (38.46 percent) were general category while 25 percent of the male groups were general caste category. Overall in the social category, general caste had the highest 11 groups (36.67 percent) followed by 8 groups (26.66 percent) from the mixed category. The percentage of SC and ST groups was 5 (18.67 percent) and 3 (10.00 percent), respectively.

Economic status of SHG: Data presented in Table 1 indicates that out of 30 groups studies, 8 groups (26.67 percent) were from below the poverty line (BPL) category and 8 groups (26.67 percent) were from above the poverty line (APL) families while 14 (46.66 percent) were from both APL and BPL families.

Table 1: Profile of vegetable farming based self help groups in Himachal Pradesh

\begin{tabular}{llll}
\hline S1. No. Parameter & $\begin{array}{l}\text { Frequency } \\
(\mathbf{n}=\mathbf{3 0 )}\end{array}$ & Percentage \\
\hline 1 & Age of self-help group (years) & \\
& (a) 3-5 & 12 & 40.00 \\
& (b) Above 5 & 18 & 60.00 \\
\hline
\end{tabular}

$2 \quad$ Size of group (no. of members)

$\begin{array}{lll}\text { (a) } 10-12 & 08 & 26.67 \\ \text { (b) 13-15 } & 15 & 50.00 \\ \text { (c) 16 and above } & 07 & 23.33\end{array}$

3 Gender

(a) Male $\quad 04 \quad 13.33$

(b) Female $\quad 26 \quad 86.67$

$4 \quad$ Social category

$\begin{array}{lll}\text { (a) General } & 11 & 36.67 \\ \text { (b) Schedule caste } & 05 & 18.67 \\ \text { (c) Schedule tribe } & 03 & 10.00 \\ \text { (d) OBC } & 03 & 10.00 \\ \text { (e) Mixed } & 08 & 26.67\end{array}$

5 Economic status

$\begin{array}{lll}\text { (a) BPL } & 08 & 26.67 \\ \text { (b) APL } & 08 & 26.67 \\ \text { (c) APL+BPL } & 14 & 46.66\end{array}$

$6 \quad$ Promoter of group
(a) DRDA
15
50.00 
$\begin{array}{lll}\text { (b) Dept. of Agriculture } & 12 & 40.00 \\ \text { (c) Others/NGOs and } & 03 & 10.00\end{array}$ Banks

$7 \quad$ Bank linkage (No. of years)
(a) 3-5
18
60.00
(b) Above 5
12
40.00

8 Training programmes for members (in last two year)
(a) 1
03
10.00
(b) 2-3
21
70.00
(c) Above 3
03
20.00

Promoter of self help groups: Table 1 reveals the majority of the groups (50.00 percent) were promoted by DRDA followed by the state department of agriculture, NGOs, and banks.

Number of years with bank linkage: It is observed that (Table 1) a good majority of the groups (60.00 percent) have had bank linkage for more than 3 years i.e., groups have saving account in banks. 40.00 percent of the groups were found with above 5 years of bank linkage.

Training programmes for members: Training to members is an essential component of a quality group. Number of trainings given to the group members in various aspects is an indicator of effective group functioning. Data depicted in Table 1 shows that in the majority of the groups (70.00 percent) members attended 2-3 training sessions for the last two years, mainly in vegetable farming. Out of total 26 women groups, 20 groups (76.92 percent) members attended 2-3 training programs during last two years while the corresponding figure for male self-help groups is 1 (25.00 percent) out of 4 . Women self-help groups members attended more training than men self-help group members.

\section{(II) Financial Sustainability of Self-help Groups}

Financial sustainability is the economic performance of the SHGs. The financial sustainability of vegetable farming-based self-help groups was assessed mainly on thrift rate, periodicity of saving, utilization of savings, credit deposit ratio, repayment performance of loan, and reason for non-repayment of the loan.

Thrift rate: Thrift is an important self-help group sustainability indicator that helps in building a good corpus for use by group members in a disciplined manner. The rate of saving has a direct bearing on the pooled fund generation, and on the other hands, it promotes the habit of saving among the members. The distribution of sample groups as per their thrift rate is presented in Table 3. The largest set of groups (18) were saving $₹ 100$ or above per month. Data in the table reveals that only 10.00 percent of groups were saving below ₹ 50.00 per month.

Periodicity of meetings: Regular meetings of group members provide strength for the effectiveness of selfhelp groups. Regular meetings bring members closer to each other, and individual member problems can be well addressed. Besides this, regular meetings also help office bearers to explain the utilization of funds which brings transparency in group working. All members must regularly save a small amount of money, which is put into a joint account with other members of the group. Loans to members are given out of these joint savings. The loans are always collateral-free, and the terms of the loan are decided by the members of the SHG. The remaining funds stay in the account and earn interest. The periodicity of saving has a direct bearing

Table 2: Gender and Social Category-wise distribution of Self-help Groups

\begin{tabular}{|c|c|c|c|c|c|c|}
\hline \multirow{2}{*}{ Gender category } & \multicolumn{5}{|c|}{ Social Category } & \multirow{2}{*}{ Total $(n=30)$} \\
\hline & General & $\mathrm{SC}$ & $\mathrm{ST}$ & OBC & Mixed & \\
\hline Women & $10(38.46)$ & $4(15.38)$ & $3(11.54)$ & $3(11.54)$ & $6(23.08)$ & $26(100.00)$ \\
\hline Men & $1(25.00)$ & $1(25.00)$ & $0(0.00)$ & $00.00)$ & $2(50.00)$ & $4(100.00)$ \\
\hline Total & $11(36.67)$ & 5 (18.67) & $3(10.00)$ & $3(10.00)$ & $8(26.66)$ & $30(100.00)$ \\
\hline
\end{tabular}

Figure in parenthesis indicate percentage. 
on the common fund of the group. It also reflects the quality of the groups. Table 3 depicts the distribution of the SHGs by the periodicity of savings. It is found that most of the groups found it convenient to save monthly, and only 10 percent of groups saved fortnightly. No group saves weekly.

Table 3: Parameters of financial sustainability for vegetable farming based SHGs in Himachal Pradesh

\begin{tabular}{llll}
\hline $\begin{array}{l}\text { S1. } \\
\text { No. }\end{array}$ pinancial sustainability & $\begin{array}{l}\text { Frequency } \\
\text { (n=30) }\end{array}$ & Percentage \\
\hline 1 & Thrift rate (₹/month) & & \\
& $\begin{array}{l}\text { (a) Up to } 49 \\
\text { (b) } 50-99\end{array}$ & 03 & 10.00 \\
& (c) 100 \& above & 18 & 30.00 \\
\hline 2 & Periodicity of meetings & 60.00 \\
& $\begin{array}{l}\text { (a) Weekly } \\
\text { (b) Fortnightly }\end{array}$ & 03 & 0 \\
(c) Monthly & 27 & 10.00 \\
\hline 3 & Utilization of SHG savings & 90.00 \\
(a) Bank saving+ cash in & 30 & 100.00 \\
hand & (b) Cash in hand & 12 & 40.00 \\
\hline
\end{tabular}

4 Credit-deposit ratio
(a) Women SHG
2.75:1
(b) Men SHG
$3.25: 1$

5 Loan Repayment

I. External loan repayment (\%)
(a) 100
18
60.00
(b) $75-99$
12
40.00
(c) $50-74$
0
(d) $<50$
0
0

II Internal loan repayment (\%)
(e) 100
12
40.00
(f) 75-99
09
30.00
(g) 50-74
06
20.00
(h) $<50$
03
10.00

6 Reason for non-repayment
(a) Natural calamity
03
10.00
(b) Family problem
15
50.00
(c) Utilization in other
09
30.00
activities
(d) Health/Illness
03

Utilization of savings by SHGs: Groups create a pool fund out of their regular savings to meet the financial necessities of the members. Loans to members are given out of these joint savings. The loans are always collateralfree, and the members of the SHG decide the terms of the loan. The remaining funds stay in the account and earn interest.. The utilization pattern of this joint fund by the groups is an essential indicator of the financial management of the group. A perusal of the Table 3 reveals that all the groups were keeping a portion of their saving in the bank as all groups are bank linked.

Credit - Deposit Ratio: The amount of bank's loan divided by the amount of its deposit at any given time gives credit- deposit (CD) ratio. The credit-deposit (CD) ratio for groups was worked out to be 0.50:1. It might be because members are cultivating vegetable in very small pieces of land, and they don't have a requirement for higher loan and the loan required for day-to-day agricultural activities is taken care of by the SHG itself.

Loan repayment performance: Table 3 represents the distribution of SHGs by the percentage of external loan repayment performance. It reveals that $60 \%$ of the sample SHG has reported 100\% loan repayment by its members. $40 \%$ of the groups reported $75-99 \%$ of loan repayment by its members. It is found that bank charges interest rate of $9-14 \%$ per year while groups charge 2.00 percent per month i.e. $24 \%$ per year to member even then members take a loan for SHG as these are readily appreciable and can be taken as small amount too.

Reasons for non-repayment of loan: There can be various reasons for non-repayment by the members. Table 3 depicts the reasons for non-repayment of loans by members. From the table, it is observed that out of 30 sample groups, 15 groups (50 percent) family problems are the main reason for non-payment of loan. In comparison, 9 groups (20 percent) cited utilization on other activities as a reason for non- repayment of loans. Natural calamity and Health/illness came as the smaller reasonss for loan repayment to the tune of $10 \%$ both.

\section{(III) Organizational sustainability}

SHG should be organizationally stable for its success. Often, lack of trust among members, non - maintaining 
records and want of co-ordination become a reason for the break-up of SHG. So, it becomes essential to analyze the organizational sustainability, and it was examined by observing the frequency of meetings, attendance in a group meeting, books maintained by the groups, dropout rates, and reasons for such dropouts.

Frequency of the group meetings: Frequency and regularity of meetings of SHG indicate group's adherence to norms of the group formation and insight into the seriousness of its functioning. The present study revealed that out of 30 sampled SHGs, 27 (90.00 percent) groups held meetings monthly (Table 5). Only three groups (10.00 percent) were observed to have a fortnightly frequency of meetings.

Table 4: Distribution of SHG's based on nature of registers maintained

\begin{tabular}{lll}
\hline Book/Record & Frequency $(\mathbf{n}=\mathbf{3 0})$ & Percentage \\
\hline Minutes Book & 30 & 100.00 \\
Saving Ledger & 30 & 100.00 \\
Loan Register & 27 & 90.00 \\
Cash Transactions & 21 & 70.00 \\
Member Passbook & 6 & 20.00 \\
General Ledger & 9 & 30.00 \\
Receipt and Payment & 15 & 50.00 \\
\hline
\end{tabular}

Attendance in group meetings: Attendance in group meetings allowed the members to participate fully in decision and remain informed about the group's activities. It is an vital indicator to evaluate the quality of the group. A perusal of the Table 5 reveals that in groups meetings, attendance above 90 percent was observed in 80.00 percent groups. 4 groups (13.33 percent) were found to have attendance between 71 to 90 percent, and only 2 groups (6.67 percent) were found having attendance percentage below 70 percent.

Nature of Books Maintained: Proper bookkeeping is of paramount importance for the effectiveness and sustainability of groups. It is one of the most critical indicators for the quality of the groups. All financial and non-financial transactions must be transparent in an SHG. This promotes trust, mutual faith and confidence among all members. Books of accounts as also other records like the saving ledger, minutes book, loan register, cash transactions, member passbook, general ledger, receipt and payment books, etc., are to be kept up to date by making regular entries transparently. All the transactions of the SHG, when recorded properly and communicated regularly, help to strengthen organizational sustainability. Table 5 depicts the nature of books maintained by the groups. It is seen that majority of SHG's (70 percent) don't have standard printed or prescribed books. 70 percent of the groups maintained different notebooks for different purposes.

Table 5: Parameters of organizational sustainability for vegetable farming based SHGs in Himachal Pradesh

\begin{tabular}{|c|c|c|c|}
\hline $\begin{array}{l}\text { S1. } \\
\text { No. }\end{array}$ & $\begin{array}{l}\text { Organizational sustainability } \\
\text { parameter }\end{array}$ & $\begin{array}{l}\text { Frequency } \\
(\mathrm{n}=30)\end{array}$ & Percentage \\
\hline \multirow[t]{4}{*}{1} & \multicolumn{3}{|l|}{ Periodicity of meetings } \\
\hline & (a) Weekly & 0 & 0 \\
\hline & (b) Fortnightly & 03 & 10.00 \\
\hline & (c) Monthly & 27 & 90.00 \\
\hline \multirow[t]{4}{*}{2} & \multicolumn{3}{|l|}{ Attendance in group meetings (\%) } \\
\hline & (a) Above 90 & 24 & 80.00 \\
\hline & (b) $71-90$ & 04 & 13.33 \\
\hline & (c) Up to 50 & 02 & 6.67 \\
\hline \multirow[t]{3}{*}{3} & No. of records maintained & & \\
\hline & (a) Up to 4 & 24 & 80.00 \\
\hline & (b) 5-7 & 06 & 20.00 \\
\hline \multirow[t]{3}{*}{4} & Nature of books maintained & & \\
\hline & $\begin{array}{l}\text { (a) Different notebooks for } \\
\text { different purpose }\end{array}$ & 09 & 30.00 \\
\hline & (b) Standard set of printed books & 21 & 70.00 \\
\hline \multirow[t]{6}{*}{5} & Reason for drop out from SHG & & \\
\hline & (a) Not getting loan/subsidy & 08 & 24.00 \\
\hline & (b) Conflict within group & 06 & 18.00 \\
\hline & (c) Migration & 04 & 12.00 \\
\hline & $\begin{array}{l}\text { (d) Not satisfied with SHG } \\
\text { functioning }\end{array}$ & 06 & 18.00 \\
\hline & (e) Death/illness & 06 & 18.00 \\
\hline
\end{tabular}

Number and Type of Records Maintained: The sample groups were found to have maintained 7 types of books/ records. However, all groups were not maintaining all 7 types of records (Table $4 \& 5$ ). It is observed that 80 percent of groups were maintaining 4 or less than 4 numbers of the register while $20 \%$ were maintaining 5-7 numbers of registers. From Table 4, it is found 
that minute's book and saving ledger was maintained by all groups. The loan register and cash transaction record were the second and third important documents maintained by 90 percent and 70 percent of the group. Relatively lesser groups were maintaining member passbook and general ledger

Drop-Out-Rate and reasons for drop-out: The reasons for drop-out constitute a varied list that illustrates the wide range of issues that $\mathrm{SHG}$ 's and their members have to deal. Table 5 analyzes the reason for drop-out stated. It was found that not getting loan /subsidy amount was the main reason reported by 24 (80.00 percent) groups followed by reasons like the conflict within the groups, non-satisfy with functioning, and death/illness.

\section{CONCLUSION}

Vegetable farming-based self-help groups have emerged as a major transformation tool for the rural economy in hills. The government of Himachal Pradesh is very keen to notice self-help groups as rural economy drivers and put many efforts to bring more farmers under the preamble of self-help groups. Merely constituting SHG and providing it with a meager amount of revolving funds does not serve the purpose but a detailed SHG profile needs to be studied to strengthen sustainability on SHGs. In the present study, SHG sustainability was embedded under two significant aspects viz economic and organizational. It was revealed in the study that both financial and organizational sustainability indicators have synergetic effects on overall group performance and these parameters have a lot of scope for improvement. Policy intervention is required to strengthen the financial sustainability of SHGs by awareness to run a business without external aid, and organizational sustainability can be strengthened by improvement in record-keeping, transparent functioning, and creating a trust of members towards their group.

\section{REFERENCES}

Ahlin, C. and Jiang, N. 2008. 'Can Micro-credit Bring Development?' J. Dev. Econ., 86(1): 1-21

APMAS. 2017. Impact and Sustainability of Self-Help Group Bank Linkage Programme in India. Hyderabad: APMAS.

Bhanot, D. and Bapat, V. 2019. Contributory Factors Towards
Sustainability of Bank-Linked Self-help Groups in India. AsiaPacific Sustain. Dev. J., 26(2).

Brown, B., Hanson, M., Liverman, D. and Meredith, R. 1987. Global Sustainability: Towards Definition. Environ. Manag., 11(6): 713-719.

Carpenter, Richards, A. 1993. Can Sustainability be Measured? Environment Strategy 5, (February), pp. 13-16.

Christen, P.B. and Ivatury, G. 2007. 'Sustainability of SelfHelp Groups in India: Two Analyses'. Occasional Paper 12. Washington, DC: CGAP.

Chopra, 1998. Watershed Development Programmes: An Evaluation of Alternative Institutional and Technological Options. Working Paper No. E/197/98/. Delhi Institute of Economic Growth.

Das, S.K. and Bhowal, A. 2014. Perception on Self-help Group's Quality Parameters: A Psychometrics Analysis. British J. Econ. Manag. Trade, 4(4): 487-522.

Das, T. and Guha, P. 2019. Measuring Women's Self-help Group Sustainability: A Study of Rural Assam. Int. J. Rural Manag., 15(1): 116-136.

Devaki, K., Mathialagan, P. and Sabarathman, V.E. 2015. Developing a Cumulative Scale for Measuring the Performance of Self-help Groups in Rural Areas. Int. J. Appl. Res., 1(10): 0814.

Government of Himachal Pradesh. 2021. Economic Survey. Saving Lives and Livelihood. 2020-2. https://himachalservices. nic.in/economics/pdf/Economic_Survey_eng2020-21.pdf

Government of Himachal Pradesh. 2021. National Rural Livelihood Mission: A Path of Self-Reliance to Women. Information and Public Relations.

Kumari, A. and Malathi, N. 2009. 'Micro Credit and Rural Development'. In Micro-credit and Rural Development, edited by A. K. Thakur and P. Sharma, 1-10. New Delhi: Deep \& Deep Publication.

Mahajan, V. 1998. 'Sustainability of MFIs'. In Microfinance in India, edited by K.G. Karmakar, 95-109. New Delhi: SAGE Publications.

Nair, A. 2005. Sustainability of Microfinance Self-help Groups in India : Would Federating Help?. Policy Research Working Paper; No. 3516. World Bank, Washington, DC. (C) World Bank. https://openknowledge.worldbank.org/handle/10986/8847 License: CC BY 3.0 IGO.

NCAER. 2008. Impact and Sustainability of SHG Bank Linkage Programme. National Council of Applied Economic Research, GTZ-NABARD, pp. 36-37.

Puhazhendi, V. and Badatya, K.C. 2002. "SHG-Bank Linkage Programme for Rural Poor- An Impact Assessment" Paper presented at seminar on SBLP at New Delhi, 25-26, November, NABARD, Mumbai. 
Ramakrishna, H., Khaja, M.J., Saleema, B. and Mallikarjuna, B. 2013. 'Performance of Self-help Group-Bank Linkage Programme in India-An Analytical Study'. Tactful Manag. Res. J., 1(10): 1-6.

Sen, M. and Sircar, A. 2012. Study of SHG \& MF sector in West Bengal with special reference to CASHE. Action research project to Loka Kalyan Parishad; 2006.

Sheikh, F. and Chauhan, A.K. 2010. Performance of dairy self-help groups (SHGs) in India: Principal component analysis (PCA) approach. Indian J. Agric. Econ., 65(2).

Singh, S., Raman, N.L.M. and Hansra, B.S. 2017. Perspectives of Agritourism in Himachal Pradesh: A New Dimension in Hill Agricultural Diversification. J. Comm. Mobil. Sustain. Dev., 12(2): 207-215.
Singh, S. and Hansra, B.S. 2021. Minimizing Vegetable Production Constraints in Hills: Boon to Attain Sustainable Vegetable Farming System. Indian J. Ext. Edu., 57(1): 52-55.

Singh, U. 2017. Self-help Groups and Women Empowerment: Appraisal of Drang Block in Mandi District of HP. Managerial Insight. The Journal of Incisive Analyzers, 13(1): 45-53.

Tankha, A. 2002. Self-help Groups as Financial Intermediaries in India: Cost of Promotion, Sustainability and Impact. New Delhi: Sa-Dhan.

Yadav, R., Sagari, M.O., Tripathi, H., Kumar, P., Balaraju, B.L., Sinha, S.K. and Nukala, R. 2016. Study of Performance of Women Based Self-help Groups at Individual Level in Rewari District of Haryana. Haryana Vet. (December, 2016) 55 (2), 206209. 
